\title{
Pengolahan Lindi Menggunakan Moving Bed Biofilm Reactor dengan Proses Anaerobik- Aerobik-Anoksik
}

\author{
Nuriflalail Rio Jusepa dan Welly Herumurti \\ Jurusan Teknik Lingkungan, Fakultas Teknik Sipil dan Perencanaan, Institut Teknologi Sepuluh Nopember (ITS) \\ Jl. Arief Rahman Hakim, Surabaya 60111 Indonesia \\ e-mail: herumurti@enviro.its.ac.id
}

\begin{abstract}
Abstrak- Lindi mengandung konsentrasi organik, Total Kjeldahl Nitrogen, amonium, nitrit dan nitrat yang tinggi sehingga lindi yang tidak diolah dapat mencemari lingkungan. Pengolahan biologis dengan sistem fluidized attached growth seperti Moving Bed Biofilm Reactor (MBBR) dapat digunakan untuk menurunkan senyawa organik dan senyawa nitrogen. Konsentrasi organik dan nitrogen yang tinggi pada lindi dapat diolah dengan mengatur proses aerobik-anaerobik-anoksik di dalam MBBR. Kapasitas pengolahan MBBR yang digunakan sebesar 10 L dan media Kaldness (K1) sebanyak 2 L. MBBR dioperasikan dengan sistem batch, dengan kondisi aerobik yang berasal dari aerator dan pompa submersible, kondisi anaerobik berasal dari pompa submersible saja, dan kondisi anoksik yang berasal dari pompa submersible dan aerator. Hasil penelitian ini menunjukkan bahwa MBBR dapat digunakan untuk menurunkan senyawa nitrogen dan senyawa organik. Efisiensi penyisihan optimum senyawa organik sebesar $87 \%$ pada proses anaerobik baik pada sistem fluidized attached growth maupun suspended growth. Efisiensi penyisihan optimum senyawa nitrogen sebesar $72 \%$ pada proses anoksik baik pada sistem fluidized attached growth maupun suspended growth.
\end{abstract}

Kata Kunci-Lindi, Moving Bed Biofilm Reactor (MBBR), Total Nitrogen, Total Organik.

\section{PENDAHULUAN}

$\mathrm{S}$ AMPAH padat di TPA tersusun oleh komponen padatan dan cairan sampah yang di dalamnya terkandung zat-zat kimia baik organik maupun anorganik yang disebut lindi. Lindi merupakan cairan yang timbul sebagai hasil dekomposisi sampah yang mengandung bahan organik tinggi. Lindi dari TPA merupakan bahan pencemar yang dapat mengganggu kesehatan manusia dan mencemari lingkungan karena di dalam lindi terdapat berbagai senyawa kimia organik maupun anorganik, sejumlah bakteri patogen, amonium, timbal, dan mikroba parasit [1]. Kualitas dan kuantitas lindi sangat bervariasi dan berfluktuasi yang dapat dipengaruhi oleh faktor-faktor seperti komposisi material sampah padat, musim, temperatur dan kelembaban, teknis operasional pengelolaan lindi, dan umur timbunan. Salah satu komponen dalam lindi yang paling penting adalah senyawa nitrogen. Senyawa nitrogen dalam lindi berasal dari sampah atau buangan. Jenisjenis nitrogen anorganik yang utama dalam air adalah nitrat nitrogen $\left(\mathrm{NO}_{3}-\mathrm{N}\right)$ dan amonium nitrogen $\left(\mathrm{NH}_{3}-\mathrm{N}\right)$, tetapi dalam kondisi tertentu terdapat dalam bentuk nitrit nitrogen $\left(\mathrm{NO}_{2}-\mathrm{N}\right)$. Kadar $\mathrm{NH}_{3}-\mathrm{N}, \mathrm{NO}_{3}-\mathrm{N}, \mathrm{NO}_{2}-\mathrm{N}$, dan TKN dalam lindi pada musim penghujan masing-masing sebesar $312 \mathrm{mg} / \mathrm{L}, 17$ mg/L, 23,8 mg/L, dan 498,4 mg/L [2]. Nitrit merupakan bentuk peralihan dari amonium menjadi nitrat yang disebut nitrifikasi. Peralihan antara nitrat dan gas nitrogen disebut denitrifikasi. Nitrifikasi berlangsung pada kondisi aerobik dan denitrifikasi berlangsung pada kondisi anoksik [3].

Konsentrasi nitrogen yang tinggi dalam air lindi berpotensi memberikan pencemaran terhadap lingkungan yang cukup besar. Masalah pencemaran yang sering dikaitkan dengan adanya senyawa nitrogen yang berlebih diantaranya:

a. Turunnya DO di sungai atau danau akibat oksidasi amonium menjadi nitrogen oksida.

b. Amonium bersifat toksik terhadap ikan-ikan.

c. Menyebabkan eutrofikasi pada danau dan air permukaan.

d. Amonium dapat mengonsumsi dosis khlorin yang berakibat naiknya kebutuhan khlor untuk desinfektan dalam proses pengolahan air minum.

Oleh karena itu, senyawa nitrogen perlu diolah dengan teknologi yang tepat sehingga air lindi tidak berbahaya terhadap lingkungan. Tidak hanya nitrogen, tetapi juga organik atau COD (Chemical Oxygen Demand) perlu diolah. Moving Bed Biofilm Reactor (MBBR) adalah salah satu unit pengolahan biologis yang memanfaatkan biofilm yaitu dengan sistem fluidized attached growth (mikroorganisme yang tumbuh pada media) tanpa terjadi clogging [4]. Moving Bed Biofilm Reactor memanfaatkan proses anaerobik untuk mengolah konsentrasi organik (COD) yang tinggi mencapai 80.000 mg/L [5]. Moving Bed Biofilm Reactor (MBBR) juga memanfaatkan proses aerobik-anoksik yang berpotensi dalam mengolah nitrogen melalui nitrifikasi dan denitrifikasi. Efisiensi removal nitrogen pada lindi dalam bentuk amonium dan nitrat melalui proses aerobik-anoksik mencapai $80 \%$ dengan konsentrasi awal $\mathrm{NH}_{3}$ dan $\mathrm{NO}_{3}$ masing-masing sebesar $2000 \mathrm{mg} / \mathrm{L}$ dan 0,5 mg/L [6]. Efisiensi optimum penggunaan MBBR dalam menurunkan konsentrasi senyawa organik maupun organik belum diketahui. Oleh karena itu, diperlukan penelitian mengenai pengolahan senyawa nitrogen dan senyawa organik secara biologis menggunakan MBBR.

\section{METODE PENELITIAN}

\section{A. Persiapan Alat dan Bahan}

Dalam penelitian ini diperlukan alat-alat dan bahan-bahan yang dibutuhkan dalam keberlangsungan penelitian. Peralatan dan bahan yang perlu disiapkan adalah sampel lindi TPA Ngipik Gresik, lumpur IPLT Keputih, aerator, pompa submersible, media Kaldness 1 (K1), glasswear, vacuum filter, cawan porselen, dan reagen yang diperlukan untuk analisis 
parameter utama dan parameter monitoring.

\section{B. Analisis Karakteristik Awal Lindi}

Sampel yang digunakan dalam penelitian ini adalah air lindi yang berasal dari TPA Ngipik yang terletak di Gresik, Jawa Timur. TPA Ngipik ini menggunakan sistem open dumping. Sampel diambil pada bulan Februari 2016. Titik pengambilan sampel pada sumur pengumpul air lindi TPA Ngipik. Pada penelitian pendahuluan dilakukan uji karakteristik lindi TPA Ngipik Gresik awal, uji MLSS lumpur IPLT Keputih awal.

\section{Seeding dan Aklimatisasi}

Seeding dilakukan untuk mendapatkan mikroorganisme yang siap digunakan ketika MBBR dioperasikan. Mikroorganisme didapatkan dari lumpur IPLT Keputih. Lumpur tersebut berasal dari RAS (Return Activated Sludge) unit Clarifier. Kemudian lindi dan lumpur IPLT Keputih dimasukkan ke dalam MBBR. Konsentrasi MLSS lumpur RAS IPLT Keputih sebesar 4000 mg/L. Aklimatisasi merupakan proses penyesuaian suatu organisme di lingkungan baru. Lindi dan lumpur dicampur di dalam reaktor yang diaerasi selama 3 hari. Volume lumpur yang dimasukkan ke dalam setiap reaktor sebanyak $2 \mathrm{~L}$ dan volume lindi sebanyak 8 L. Kondisi steady state dapat dicapai apabila efluen sampai mempunyai nilai konsentrasi COD yang konstan atau stabil yaitu ketika efisiensi penyisihan COD mencapai 80\% [7]. Setelah mencapai kondisi steady state, maka sejumlah sampel disimpan di dalam sebuah tangki sebagai stok lumpur agar setiap kali membutuhkan sampel sudah tersedia yang sudah teraklimatisasi.

\section{Pembuatan Reaktor}

Reaktor yang digunakan untuk pengolahan lindi adalah pipa PVC dengan diameter sekitar $10 \mathrm{~cm}$ dan tinggi $200 \mathrm{~cm}$. Volume pengolahan pada reaktor MBBR batch adalah $10 \mathrm{~L}$. Konsentrasi MLSS yang dibutuhkan di dalam MBBR adalah $4000 \mathrm{mg} / \mathrm{L}$. Media terendam yang digunakan yaitu tipe Kaldness (K1) (Gambar 1) karena media yang ideal yang digunakan untuk proses dalam MBBR adalah media yang tipis dan pergerakan media merata. Media terendam sebanyak (2050)\% dari volume reactor. Ilustrasi reaktor MBBR dapat dilihat pada Gambar 1.

\section{E. Pelaksanaan Penelitian}

Penelitian ini untuk menentukan kemampuan MBBR dalam menurunkan konsentrasi nitrogen dan konsentrasi organik yang dilakukan selama 20 hari. Analisis parameter dilakukan sebelum proses anaerobik, setelah proses anaerobik, setelah proses aerobik, dan setelah proses anoksik.

Proses anaerobik tanpa menggunakan aerator dan pompa submersible, proses aerobik dibuat dengan menyalakan aerator dan pompa submersible, dan proses anoksik dibuat dengan menyalakan pompa submersible dan menggunakan aerator selama 12 jam kemudian 12 jam berikutnya aerator dimatikan. Di dalam reaktor batch aliran air yang masuk, diaduk sempurna, diolah, dan dikeluarkan begitu seterusnya.

\section{F. Analisis Data dan Kesimpulan}

Pembahasan mengenai hubungan antara satu parameter dengan parameter yang lain dan sebab akibat adanya hasil yang tidak sesuai dengan teori. Kesimpulan disusun berdasarkan hasil analisis data penelitian serta pembahasan. Kesimpulan berisi jawaban atas rumusan masalah dan sebanding dengan yang diharapkan dalam penelitian. Kesimpulan merupakan poin - poin yang dapat dibuat secara ringkas dari pembahasan yang dibuat.

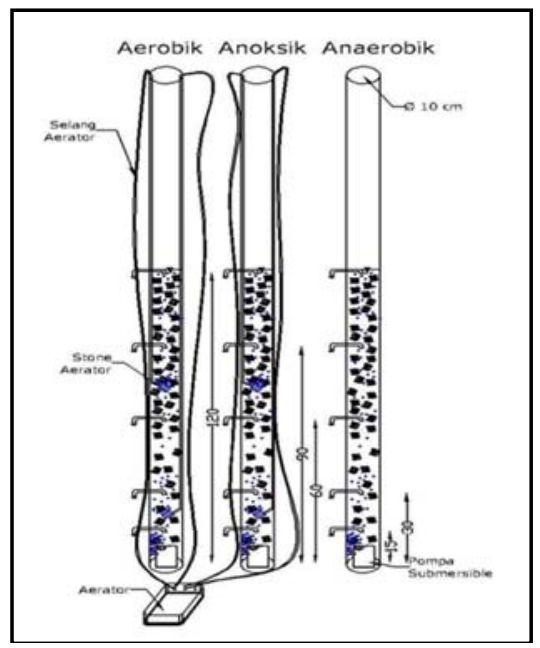

Gambar 1. Ilustasi Reaktor MBBR

\section{HASIL DAN PEMBAHASAN}

\section{A. Penurunan Massa Senyawa Nitrogen}

Penyisihan massa nitrogen menggunakan tiga macam reaktor yaitu reaktor aerobik, anaerobik, dan anoksik. Proses yang terjadi dalam reaktor aerobik adalah nitrifikasi. Proses yang terjadi dalam reaktor anaerobik adalah nitritasi dan anammox. Proses yang terjadi di dalam reaktor anoksik adalah denitrifikasi.

Reaktor dengan kondisi aerobik terjadi proses nitrifikasi. Antara sistem fluidized growth dengan suspended growth yang memiliki efisiensi penyisihan senyawa nitrogen terbesar adalah sistem suspended growth yaitu 62\% dikarenakan bakteri Nitrosomonas dan Nitrobacter sudah mampu mengoksidasi amonium nitrogen menjadi nitrit nitrogen kemudian nitrit nitrogen dioksidasi menjadi nitrat nitrogen. Reaksi biokimia proses nitrifikasi sebagai berikut,

$$
\begin{aligned}
& \mathrm{NH}_{4}{ }^{+}+1,5 \mathrm{O}_{2} \rightarrow \mathrm{NO}_{2}{ }^{-}+\mathrm{H}_{2} \mathrm{O}+2 \mathrm{H}^{+}+\text {energi. } \\
& \mathrm{NO}_{2}{ }^{-}+0,5 \mathrm{O}_{2} \rightarrow \mathrm{NO}_{3}{ }^{-}+\text {energi... } \\
& \mathrm{NH}_{4}^{+}+2 \mathrm{O}_{2} \rightarrow \mathrm{NO}_{3}^{-}+2 \mathrm{H}^{+}+\mathrm{H}_{2} \mathrm{O}
\end{aligned}
$$

Perbandingan prosentase massa nitrogen yang terolah antara kedua sistem dapat dilihat pada Gambar 3. Mass balance senyawa nitrogen dapat dilihat pada Gambar 1.

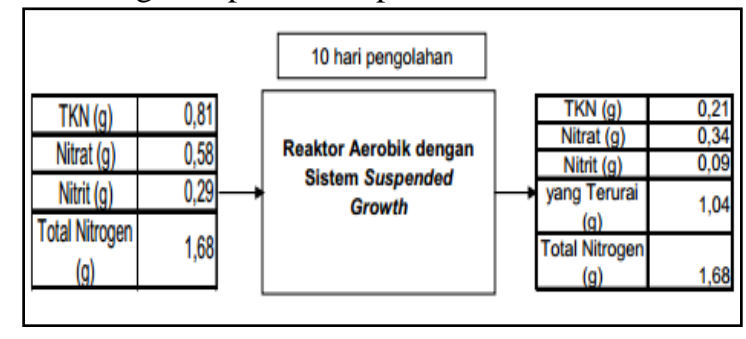

Gambar 1. Mass Balance Senyawa Nitrogen Proses Aerobik Sistem Suspended Growth 
Reaktor dengan kondisi anaerobik terjadi proses nitritasi dan anammox dengan persamaan sebagai berikut,

$\mathrm{NH}_{4}{ }^{+}+3 / 2 \mathrm{O}_{2} \rightarrow \mathrm{NO}_{2}^{-}+\mathrm{H}_{2} \mathrm{O}+2 \mathrm{H}^{+}$.

$\mathrm{NH}_{4}{ }^{+}+1,32 \mathrm{NO}_{2}{ }^{-}+0,066 \mathrm{HCO}_{3}{ }^{-}+0,13 \mathrm{H}^{+} \rightarrow 1,02 \mathrm{~N}_{2}+$

$0,26 \mathrm{NO}_{3}^{-}+0,066 \mathrm{CH}_{2} \mathrm{O}_{0,5} \mathrm{~N}_{0,15}+2,03 \mathrm{H}_{2} \mathrm{O}$.

Jadi, sebagian dari amonium nitrogen dioksidasi oleh bakteri anaerobik menjadi nitrit nitrogen dengan keadaan oksigen terbatas. Kemudian sisa dari amonium nitrogen dan nitrit yang terbentuk dikonversi menjadi $\mathrm{N}_{2}$ gas yang dilepas ke atmosfer. Antara kedua sistem untuk proses anaerobik yaitu sistem suspended growth mampu menyisihkan oksigen sebesar $71 \%$ daripada sistem fuidized growth sebesar 65\%. (Gambar 6). Bakteri anammox dapat mengoksidasi amonium nitrogen secara anaerobik karena memiliki enzim hydrazine hydrolase (HH), hydrazine oxidizing (HZO), dan nitrite reducing (NR) [8]. Mass balance senyawa nitrogen proses anaerobik sistem suspended growth dapat dilihat pada Gambar 5.

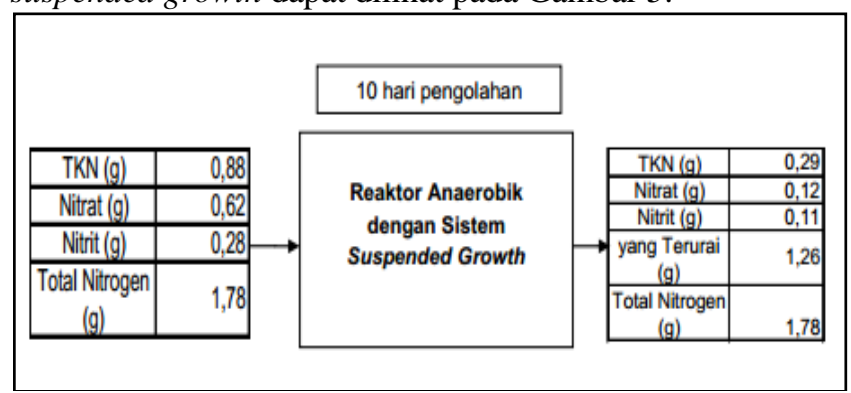

Gambar 2. Mass Balance Senyawa Nitrogen Proses Anaerobik Sistem Suspended Growth

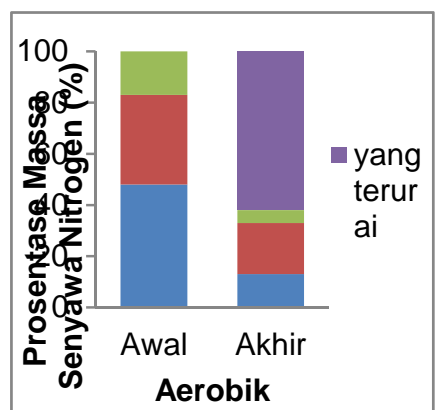

(a)
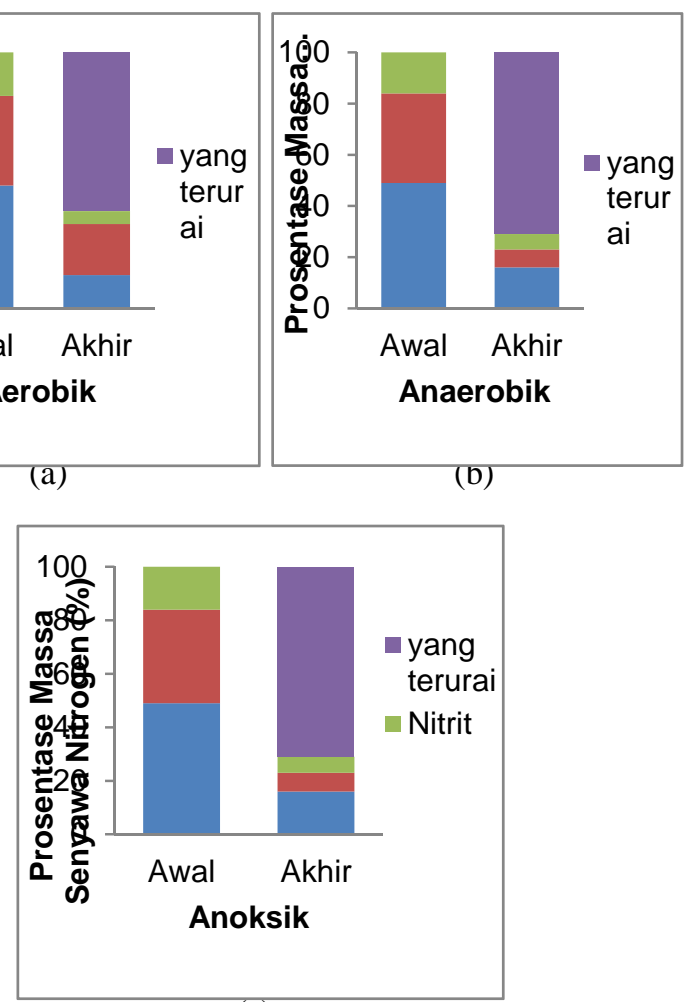

(c)

Gambar 3. Nitrogen Balance Sistem Suspended Growth, (a) proses aerobik, (b) proses anaerobik, (c) proses anoksik
Reaktor dengan kondisi anoksik terjadi proses denitrifikasi, tetapi di dalam reaktor ini terindikasi adanya proses nitrifikasi karena di dalam proses anoksik selama 12 jam aerator dan pompa submersible menyala. Antara sistem fluidized growth dan suspended growth penyisihan senyawa nitrogen terbesar pada sistem suspended growth yaitu $72 \%$, sedangkan sistem fluidized growth sebesar 68\% (Gambar 3). Bakteri denitrifikasi mampu menyisihkan senyawa nitrogen mencapai 70\% lebih dikarenakan bakteri denitrifikasi (fakultatif anaerob) memanfaatkan keadaan anoksik untuk mengoksidasi senyawa nitrogen menjadi $\mathrm{N}_{2}$ gas yang dilepas ke atmosfer. Mass balance senyawa nitrogen proses anoksik dengan sistem suspended growth dapat dilihat pada Gambar 4.



Gambar 4. Mass Balance Senyawa Nitrogen Proses Anoksik Sistem Suspended Growth

Jadi, dapat disimpulkan bahwa efisiensi penyisihan senyawa nitrogen dengan kondisi aerobik $(68 \%)<$ anaerobik $(71 \%)<$ anoksik $(72 \%)$. Kemudian dari semua proses, sistem suspended growth mempunyai efisiensi penyisihan nitrogen yang lebih tinggi dengan fluidized growth, tetapi tidak berbeda jauh. Salah satu kelebihan dari fluidized growth adalah tidak perlu adanya resirkulasi lumpur sehingga jumlah bakteri relatif sedikit dibandingkan proses lumpur aktif. Kelebihan itulah yang menyebabkan efisiensi antara kedua sistem tidak berbeda jauh.

\section{B. Analisis Biomasa Sebagai MLSS}

Ketersediaan mikroorganisme di dalam reaktor dapat diketahui melalui pengukuran MLSS. Selain itu, pengukuran biomasa dengan jumlah MLVSS juga dilakukan untuk mengetahui besar perbandingan jumlah makanan atau organik dengan mikroorganisme yang tersedia (rasio F/M) di dalam reaktor. Mengaplikasikan reaktor dengan kondisi anaerobik, aerobik, dan anoksik memungkinkan akan memproduksi lumpur. Konsentrasi MLSS akan meningkat karena adanya pertumbuhan dan perkembangbiakan dari mikroorganisme di dalam reaktor.

Antara sistem fluidized growth dan suspended growth nilai MLSS paling banyak adalah pada sistem suspended growth dapat dilihat pada Gambar 5 dan Gambar 6. Reaktor dengan kondisi aerobik memiliki pertumbuhan mikroorganisme yang lebih tinggi dibandingkan dengan anoksik maupun anaerobik baik sistem fluidized growth maupun suspended growth dikarenakan mikroorganisme dengan menggunakan oksigen terlarut (DO) untuk proses asimilasi atau pembentukan mikrooganisme baru (berkembang biak) mendapatkan energi lebih banyak daripada mengggunakan oksigen terikat. 


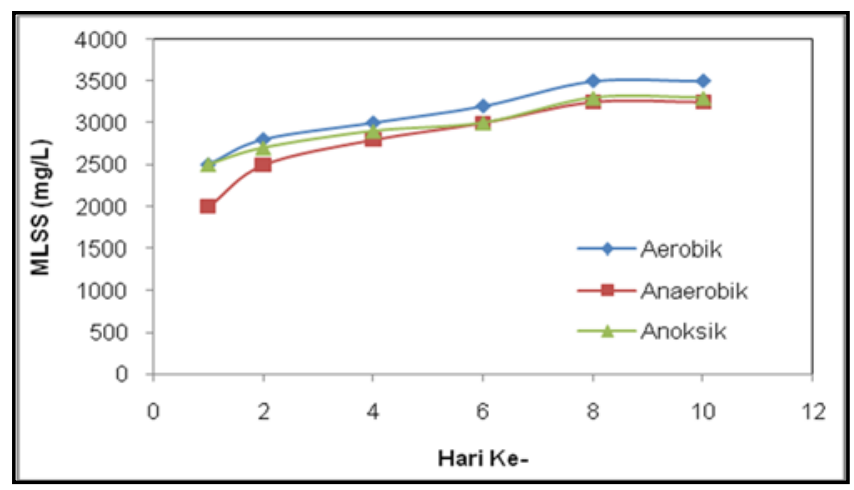

Gambar 5. Konsentrasi MLSS Sistem Suspended Growth

Begitu pula dengan sistem fluidized growth, reaktor dengan kondisi aerobik memiliki nilai MLSS paling tinggi diantara kondisi anaerobik dan kondisi anoksik (Gambar 8). Reaktor dengan kondisi aerobik, mikroorganisme aerobik lebih aktif dalam mendegradasi senyawa organik maupun senyawa nitrogen yang terdapat di dalam lindi.

Semakin banyak MLSS yang digunakan dalam sistem pengolahan, mengindikasikan bahwa terdapat lebih banyak mikroorganisme pengurai dalam sistem tersebut sehingga aktivitas penguraian bahan organik dan nitrogen yang terkandung dalam lindi lebih cepat [9]. Begitu juga dengan reaktor kondisi anaerobik maupun anoksik semakin hari semakin bertambah nilai MLSS, tetapi tidak sebanyak reaktor aerobik.

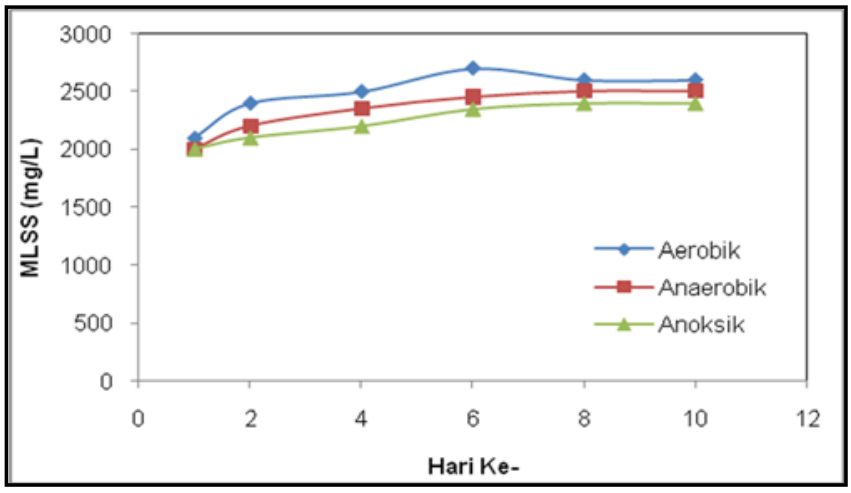

Gambar 6. Konsentrasi MLSS Sistem Fluidized Growth

\section{Analisis $F / M$}

Sebuah parameter proses yang biasanya digunakan untuk mendesain karakteristik proses dan keadaan operasi yaitu rasio makanan (COD) per mikroorganisme (biomasa atau MLVSS). Nilai tipikal untuk rasio F/M berdasarkan kebanyakan literatur yaitu sebesar 0,04-1,0 g organik/g biomasa.hari untuk sebuah proses aerasi yang tergolong high rate process. Berdasarkan hasil sistem fluidized attached growth, rasio F/M mengalami penurunan baik reaktor dengan proses aerobik, anaerobik, maupun anoksik (Gambar 7 dan Gambar 8) dikarenakan jumlah mikroorganisme sudah sesuai untuk mendegradasi polutan. Begitu juga terjadi pada reaktor dengan sistem suspended growth menunjukkan bahwa rasio F/M mengalami penurunan baik proses aerobik, anaerobik, dan anoksik. Rasio F/M kedua sistem dapat dilihat pada Gambar 7 dan Gambar 8.



Gambar 7. Rasio F/M Sistem Fluidized Attached Growth

Reaktor dengan kondisi aerobik, anaerobik, dan anoksik memiliki kemampuan aktivitas dalam mendegradasi senyawa organik maupun senyawa nitrogen yang hampir sama. Reaktor dengan kondisi aerobik, anaerobik, dan anoksik yang ditambahkan pengadukan di dalam reaktor dapat membuat kontak antara biofilm dan polutan sehingga ini sangat memungkinkan untuk mengaplikasikan proses MBBR untuk mengolah lindi.

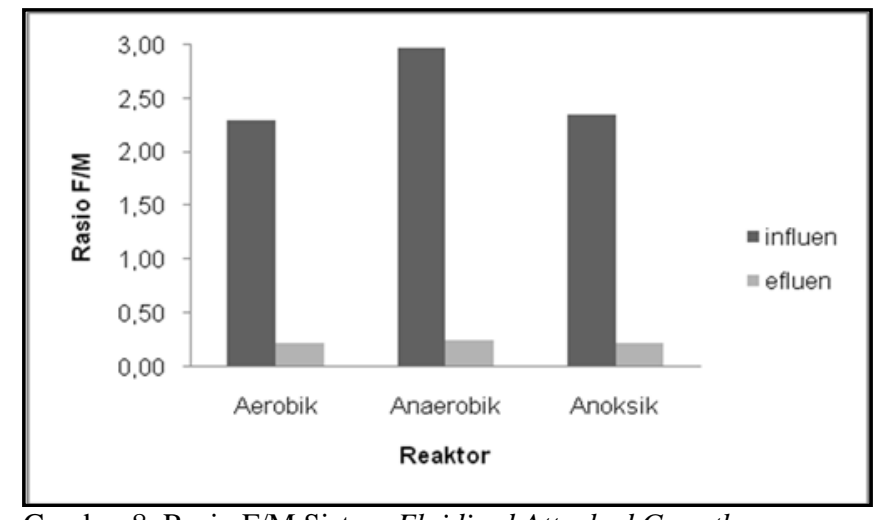

Gambar 8. Rasio F/M Sistem Fluidized Attached Growth

\section{Analisis Salinitas}

Analisis salinitas merupakan parameter monitoring di dalam penelitian ini. Pengukuran salinitas dengan menggunakan $p H$ onlab-EC 10. Salinitas dibutuhkan mikroorganisme dalam jumlah kecil sehingga MBBR tidak memberikan pengaruh terhadap penurunan salinitas. Unsur utama dalam salinitas adalah klorida $\left(\mathrm{Cl}^{-}\right)$yang merupakan bahan anorganik. Berdasarkan hasil penelitian, nilai salinitas untuk sistem fluidized attached growth berkisar antara 1,2-1,8 ppt. Nilai salinitas sistem suspended growth berkisar antara 0,8-1,6 ppt (Gambar 9). Nilai salinitas tersebut tergolong moderate halophilic yang termasuk sebagai kondisi air payau dengan salinitas kecil [10] sehingga nilai salinitas tidak mempengaruhi proses biologis yang ada di dalam reaktor. Apabila nilai salinitas yang tinggi dapat menyebabkan terjadinya plasmolisis pada mikroorganisme. Apabila kadar garam tinggi dalam lindi, maka bakteri memerlukan energi 
tambahan untuk fiksasi karbon dan untuk mempertahankan tekanan osmotik.

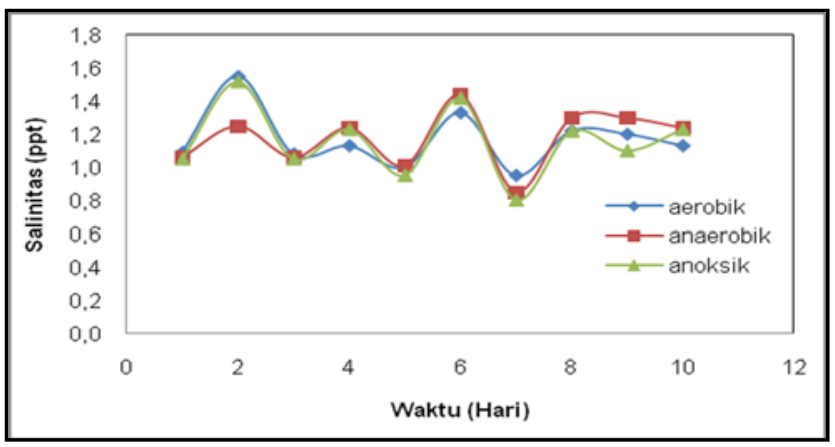

Gambar 9. Analisis Salinitas Sistem Suspended Growth

\section{E. Analisis $p H$}

Analisis $\mathrm{pH}$ merupakan parameter monitoring di dalam penelitian ini. Pengukuran $\mathrm{pH}$ menggunakan Basic $\mathrm{pH}$ meter 03771 Denver Instrument. Analisis nilai pH dapat dilihat pada Gambar 10.

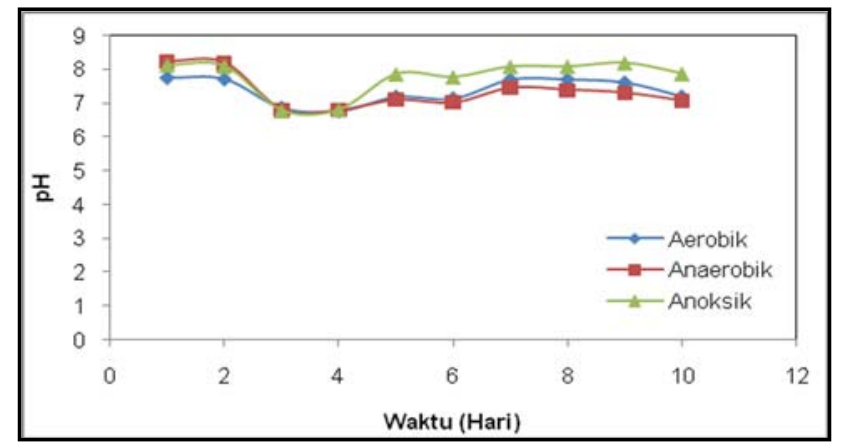

Gambar 10. Analisis pH Sistem Fluidized Growth

Berdasarkan hasil analisis yang dilakukan, nilai pH dengan pengolahan sistem fluidized attached growth berkisar antara 6,79-8,24 (Gambar 10). Sementara itu, nilai pH dalam reaktor dengan sistem suspended growth berkisar antara 6,87-8,27. Baik dalam sistem fluidized attached growth maupun suspended growth dalam proses aerobik, anaerobik, dan anoksik nilai $\mathrm{pH}$ mengalami penurunan dari hari ke-2 sampai hari ke-4 dan kemudian naik kembali. Penurunan $\mathrm{pH}$ diakibatkan oleh adanya pembentukan nitrat nitrogen dari amonium nitrogen. Kenaikan $\mathrm{pH}$ diakibatkan adanya proses oksidasi nitrat nitrogen menjadi $\mathrm{N}_{2}$ gas yang dilepas ke atmosfer.

\section{F. Analisis Alkalinitas}

Analisis alkalinitas merupakan parameter monitoring di dalam penelitian ini. Alkalinitas adalah kemampuan air untuk menetralkan tambahan asam tanpa menurunkan nilai $\mathrm{pH}$ larutan. Berdasarkan Gambar 11 nilai alkalinitas mengalami naik turun baik pada proses aerobik, anaerobik, dan anoksik.

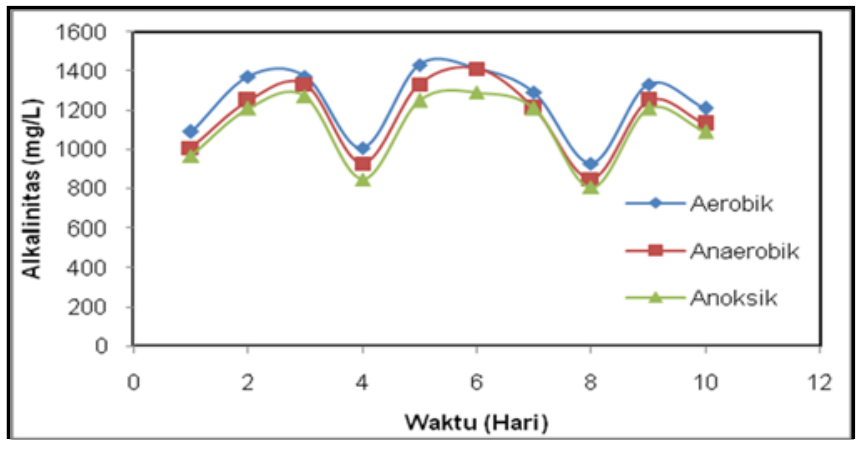

Gambar 11. Analisis Alkalinitas Sistem Suspended Growth

Reaktor dengan proses aerobik mikroorganisme menggunakan alkalinitas sebagai substrat sehingga nilai alkalinitas menurun. Kemudian pada reaktor dengan kondisi anaerobik terjadi peningkatan nilai alkalinitas seiring bertambahnya konsentrasi amonium nitrogen. Selanjutnya, reaktor dengan kondisi anoksik akan meningkatkan alkalinitas dikarenakan pda proses denitrifikasi memproduksi alkalinitas.

\section{KESIMPULAN}

Penelitian pengolahan senyawa nitrogen dan senyawa organik menggunakan MBBR (Moving Bed Biofilm Reactor) dan SBR (Sequencing Batch Reactor) dengan proses anaerobik, aerobik, dan anoksik menghasilkan kesimpulan bahwa efisiensi penyisihan optimum senyawa nitrogen mencapai $72 \%$ pada proses anoksik, $71 \%$ proses anaerobik, dan 68\% proses aerobik. Proses anoksik memiliki efisiensi yang paling besar dikarenakan proses penyisihan nitrogen pada reaktor anoksik sampai pada pelepasan $\mathrm{N}_{2}$ gas ke atmosfer. Efisiensi penyisihan optimum senyawa organik mencapai $88 \%$ pada proses anaerobik dan anoksik serta $87 \%$ pada proses aerobik.

\section{UCAPAN TERIMA KASIH}

Terima kasih penulis tujukan kepada segenap pihak dari DKP Kota Surabaya, DKP Kota Gresik, dan TPA Ngipik Gresik atas bantuan dan dukungan dalam penyelesaian penelitian ini.

\section{DAFTAR PUSTAKA}

[1] Susanto, P. J., Ganefati, P. S., Muryani, S., dan Istiqomah, H. S. 2004. Pengolahan Lindi dari TPA dengan Sistem Koagulasi-Biofilter Anarobik. Jurnal Tenik Lingkungan P3TL-BPPT, 05, 167-173.

[2] Susanto, P. J., Ganefati, P. S., Muryani, S., dan Istiqomah, H. S. 2004. Pengolahan Lindi dari TPA dengan Sistem Koagulasi-Biofilter Anarobik. Jurnal Tenik Lingkungan P3TL-BPPT, 05, 167-173.

[3] Effendi, H. 2003. Telaah Kualitas Air bagi Pengelolaan Sumber Daya dan Lingkungan Perairan. Cetakan Kelima. Yogjakarta : Kanisius.

[4] Metcalf dan Eddy. 2003. Wastewater Engineering Treatment and Reuse. Mc Graw Hill Company, New York.

[5] Ikbal. 2005. Aplikasi Proses Biologi Anaerobik pada Pengolahan Air Limbah Organik Berkonsentrasi Garam Tinggi. Jurnal Air Indonesia, 1 (2).

[6] Miao, L., Wang, K., Wang, S., Zhu, R., Li, B., Peng, Y., dan Weng, D. 2014. Advanced Nitrogen Removal from Landfill Leachate Using RealTime Controlled Three-Stage Sequence Batch Reactor (MBBR) System. Bioresource Technology, 159, 258-265. 
[7] Chen, S., Sun, D., Chung, J.-S. 2008. Simultaneous Removal of COD and Amonium from Landfill Leachate Using an Anaerobic-Aerobic Moving-Bed Biofilm Reactor System. Waste Management. 28 (2008) 339-346.

[8] Jung, J.Y., Kang, S.H., Chung,Y.C. dan Ahn, D.H. 2007. Factors Affecting the Activity of Anammox Bacteria during Start-up in the Continuous Culture Reactor, Water Science Technology, (55): 459-468.

[9] Agustiyani, D dan H. Imamuddin. 2000. Pertumbuhan Kultur Nitrifikasi Campuran Pada Senyawa Amonium. Proseding Seminar Nasional Biologi XVI dan Kongres Nasional Perhimpunan Biologi Indonesia (PBI) XII, Bandung.

[10] Agustiningsih, D., Sasongko, S. B., \& Sudarno. 2012. Analisis Kualitas Air dan Strategi Pengendalian Pencemaran Air Sungai Blukar Kabupaten Kendal. Jurnal Presipitasi Vol.9 No.2, 64-71. 